\title{
Berufsverbote continues in spite of resolutions
}

West German campaigners against Berufsverbot are planning to mark Human Rights Day, 10 December, with a petition to the Federal Chancellor, asking that the promised "liberalisation" of employment policy be implemented. Vera Rich talked to a leading member of the campaign about the effect of Berufsverbot on academic life.

BERUFSVERBOT is the denial of professional employment in the government service to persons of allegedly left-wing views. It affects West German universities and academic institutions because the funding of such bodies by the state means that their staff are "state employees" - in the same category as train drivers and postal clerks. Nevertheless, and rather strangely in view of Germany's previous experience of political disruption of academic life during the 1930 s - it was only relatively late in the anti-Berufsverbot campaign that certain universities and academic bodies began to take a stand on Berufsverbot.

6 the social-liberals are
convinced that
Berufsverbote must end -
but it still hasn't stopped

In recent months, resolutions condemning Berufsverbot as a threat to academic liberty have been passed by the senates of the Universities of Oldenburg, Bremen, and Bielefeld, and the Deutsche Gesellschaft für Sociologie, amongst others. In the words of the Bielefeld protest (17 January 1979), the "autonomy of scientific work guaranteed by the German Federal Constitution forbids any attempt to exploit the scientist's status as a civil servant, to supervise his scientific activity by means of methods which are alien to science, or to derive restrictions on scientific activity from the loyalty and allegiance owed by the civil servant"'. The present practice of "screening and punishment for political beliefs", said the senate, "contradicts the liberal and democratic principles of our constitution," and, together with the administrative decrees on which it is based, "must be declared null and void".

Nevertheless, within a few weeks, Jan Priewe, selected by Bielefeld University as assistant professor of sociology was subjected to an Anhorungdverfahren (interrogation process) based on alleged left-wing activities more than five years previously.

Dr Andreas Dress, a leading campaigner against academic Berufsverbot, told Nature that it was precisely this screening process which was to have been "liberalised", but that "in fact almost nothing has changed. What we wanted was an end to the involvement of the Verfassungsschutz (Security Service) in job placements". In his own Land (province) of North-Rhine-Westphalia, for example, applicants have to fill in a form giving all their addresses for the last five years. This list then goes on to the Verfassungschutz computer, "proving," he said, "that the state government does not trust its citizens. But in a democracy, the state exists for the good of the citizens - and the Federal Republic of Germany is a democracy! This convinced the social-liberals that the practice must end".

"But it hasn't stopped," he added, "which is why we have organised the current protest. And even if it did officially stop, the personnel section could always pass on addresses to the Verfassungschutz. Still, it would be something if the practice were stopped at least officially."

"We are not arguing about genuine security checks," he went on. "We accept that they have to exist. But security can go too far. One politician, for example, justified Berufsverbot on the railways by noting that, during the Nazi occupation of France, French resistance railway workers had been able to half the whole country's rail traffic!"

Within the universities, Dr Dress explained, there is no over-all policy of screening one faculty more closely than another - sociologists, say, more than mathematicians. Some institutions, however, seem more at risk than others. Thus in the Max-Planck Institute of Biology, Chemistry and Physics in Gottingen, screening procedures do not seem to have been applied.

On the other hand, certain universities - Bielefeld included - seem to have more than their fair share of Berufsverbot cases. This, explained Dr Dress, is a result of the more liberal and open-minded attitude of such universities to innovations in course structure and content. Potential victims of Berufsverbot, he said, are less likely to apply to highly traditional establishments, either because they feel they would have no chance of acceptance, or simply because that particular milieu does not attract them. He cited the example of Horst Eckhart Gross, a victim of Berufsverbot screening when he applied for a post at the University of Oldenburg. Previously, Gross had directed a Bielefeld research project on the non-academic job deployment of mathematicians.

Of university cases of Berufsverbot, said Dr Dress, some $80 \%$ related to alleged past or present membership of the Communist Party or the "Spartakus" Marxist student union - both, he stressed, legal organisations. Some $10 \%$ of cases, mostly in Bavaria, relate to left-wing Social Democrats, and the remainder to miscellaneous left-wing groups. Formally, Berufsverbot should also cover far-right extremists, but according to Dr Dress such cases virtually never occur.

To date, Dr Dress knows of some 4,000 Berufsverbot interogation procedures. These involve prolonged waiting, and, in some of the German Lander, such as Bavaria, those undergoing investigation are not allowed to use the services of a lawyer, while in North-Rhine-Westphalia, the right to legal assistance was won only after "a long struggle". Out of the 4,000 cases some 3,000 ended either with reinstatement in the desired post, or else in the applicant abandoning his claim and taking a job in the private sector. Some 1,000 clear cases of Berufsverbot remain on the campaigners' files. However, Dr Dress went on, academics have no "private sector" to go to.

The anti-Berufsverbot campaign assesses all alleged cases very carefully. Problems of student activists expelled for poor academic performance cannot strictly speaking be considered as Berufsverbot. Nor can the recent case - described by Die Welt as "grotesque" - of a biologist charged under the German Official Secrets Act for having given his East German brother-in-law an offprint of one of his openly published papers - this was a technical breach of the law. To the antiBerufsverbot campaigners, it is important that all provocation be seen to come from the official side. "We are really only interested", said Dr Dress, "in cases where the authorities state in writing that the person is banned from employment on political grounds only. Then we can fight."

\section{6 over 70 million DM has been spent in counter- propaganda. 9}

The authorities, incidentally are not slow to take counter-measures against the damage done to their image abroad by the anti-Berufsverbot campaign. Dr Dress recalled that in April of this year, the Christian Democrats tabled a question in the Federal Parliament, demanding to know what the ruling Socialist-Liberal coalition had done to neutralise the influence of the campaigners. To date, according to the official reply, over 70 million DM has been spent in counterpropaganda, mostly among journalists in foreign countries. It is perhaps for this reason, Dr Dress concluded, that initiatives from the campaigners, such as the establishment last February of the "Heinrich Heine Fund" for victims of Berufsverbot, receive little publicity abroad. 